\title{
斜張橋ケーブルの最適プレストレス量決定に関する研究
}

\section{STUDIES ON OPTIMIZATION OF CABLE PRESTRESSES OF CABLE STAYED BRIDGES}

\author{
山田善一*.古川浩平**・江草 拓***. 井上幸一****
}

By Yoshikazu YAMADA, Kohei FURUKAWA, Taku EGUSA and Kohichi INOUE

\begin{abstract}
The cable stayed bridge can be designed economically by introducing the cable prestresses. It is the most important and difficult problem to determine the optimum cable prestresses in the design of cable stayed bridges. However, there are few studies on the optimum cable prestresses. In this study, an attempt is made to determine the optimum cable prestresses based on the strain energy criterion. The validity of the strain energy criterion on the optimum cable prestresses is proved by simple models. This proposed method is applied to some actual cable stayed bridges. The results show that the proposed strain energy criterion is very useful to determine the optimum cable prestresses even in the case of multi-cable types.
\end{abstract}

\section{1. 緒言}

近年, 斜張橋が数多く建設されるようになってきた. その理由として, 機能的な美しさに加え, ケーブルプレ ストレスという内部不静定力の導入により, 構造各部の 応力状態をかなり自由に設定でき，その結果他の形式よ り軽量化を図れることが挙げられる1).この導入プレス トレス量の決定は, 斜張橋の設計において最も重要でか つ難しい問題の 1 つであるが，この決定を合理的に行う ために最適化手法を応用した研究はほとんど見当たらな W.

斜張橋の最適化という観点からは, プレストレスの最 適化と部材断面の最適化の両者を行う必要があるが, こ の両者を同時に取り扱うと問題が非常に複雑になり，ま た以下に述べるプレストレス最適化の定式化が難しいこ ともあり, 斜張橋の最適化に関する研究の大部分は断面 のみを対象としてきた. たとえば，山田・大宮司の研

* 正会員 工博 京都大学教授 工学部土木工学科 ( ( 606 京都市左京区吉田本町)

** 正会員 工博 山口大学助教授 工学部建設工学科 ( ₹755 宇部市常盤台)

*** 正会員 三菱重工業(株)広島造船所鉄構部橋梁設計課長 ( ₹733 広島市中区江波沖町)

**** 工修 三菱重工業(株)広島造船所鉄構部橋梁設計課 (同上)
究2), 前田・林の研究3)などである.

斜張橋の設計においてケーブルプレストレスを導入す る目的は，「構造物に望ましい応力状態を出現させる」 ことにある.換言すると、「部材の断面力分布を均等化し， かつその断面力をできるだけ小さくする」と要約できる. これはかなりあいまいな目的であり，最適化において定 式化することが難しい，なぜなら，全体としての目的関 数であるコストあるいは重量の最小化と上記のプレスト レス量最適化とは直接的な結びつきが小さいことが挙げ られる. 確かにプレストレスを最適化することにより， 断面力を小さくかつ均一化でき, その結果部材断面を小 さくできるが, その関係は直接的でない，そのため従来 の研究の多くは, プレストレスの重要性については言及 しつつ,最適化過程ではプレストレスは別個に取り扱い, 既知のプレストレスのもとでケーブルを含めた部材断面 の最適化を行ってきた.

このようにプレストレス導入の目的があいまいで, そ の最適性を明確に規定できなかったため, 従来の設計例 においては, 設計者はプレストレス量を変化させてさま ざまな応力状態を作り，その中から上記の目的に対して 最も望ましいと思われるものを 1 つ選んでいた。ところ がこの選ぶ規準が必ずしも明確でないうえ，特にマルチ ケーブルの場合に応力状態に対するケーブルプレストレ 
スの影響が複雑なため，この計算に多大な労力と時間を 費やし，しかも，決定されたプレストレス量が最適であ るかどうかの疑問が残る。

本研究は従来ほとんよ゙取り扱われていなかった最適な ケーブルプレストレス量の決定法に着目する，つまり， 与えられた部材断面と載荷条件のもとで, 最も望ましい 応力状態を示すプレストレス量を決定しようとするもの である.したがって，プレストレス決定後断面が修正さ れ，さらにその断面に対するプレストレスを決定すると いう反復は通常の設計プロセスと同じである．この断面 決定に最適化手法を応用することは可能であるが, 問題 が非常に複雑になるため本研究では扱わない。

すでに述べたように，プレストレス最適化の目的があ いまいなため, 本研究においては次のような最適性の規 準を導入する．すなわち，「構造物に貯えられるひずみ エネルギーを最小にするプレストレス量の組合せが最適 である」.この最適性規準を導入することにより，(1)あ いまいであった目的が明確になり，かつ定量的に扱える ため最適化における定式化が簡単になる. (2)目的関数が 二次形式となり, 最適化が容易であり, かつ収束も早い, という利点がある.この最適性規準の妥当性に関しては 2.で詳細な検討を加える．以下，3．で定式化，4. で実 際の設計例をもとにした計算例を示す. 最後に5. で本 研究の結論を述べる.

\section{2. ひずみエネルギー規準と最適プレストレス量}

すでに1.で述べたように，ケーブルプレストレスを 導入する目的は，部材の断面力分布を均等化し，かつそ の断面力をできるだけ小さくすることにある．このこと を曲げモーメント $M$ について簡単な形で数学的に表現 すれば, 次のようになる。

規準 I $V=\int_{0}^{l}(M-\bar{M})^{2} d x \rightarrow \min$

規準 II $|\bar{M}|=\frac{1}{l}\left|\int_{0}^{l} M d x\right| \rightarrow \min$

ここに, $\bar{M}$ は $\boldsymbol{M}$ の平均值である.

この 2 式を同時に満足する解が最適プレストレスとな るが, 上記の問題は多目的最適化問題であり, 解くのは 容易ではない，そのため本研究では，これらの規準とは 別に次に示すひずみエネルギー規準も合わせて考える。

$$
\text { 規準 III } U=\int_{0}^{l} \frac{M^{2}}{2 E I} d x \rightarrow \min
$$

すでに述べた式（1），（2）の規準と式（3）の規準と の関連を以下の簡単な構造物を用いて検討する.

まず図一1に示す等分布荷重 $q$ を受けるはりの中央上 向きに, $P$ というプレストレスがかかっている構造物 を考える.この構造物に対し，上記の規準 I，II， IIIに 関する結果をまとめたものを図一2に示す。式（2）に

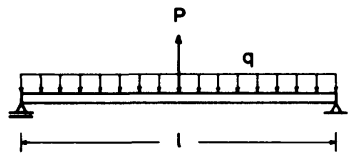

図一1 朝力の影需がない 1 变数凮題の例

\begin{tabular}{|c|c|c|c|}
\hline 规淃 & $\begin{array}{c}\mathrm{I} \\
(\mathrm{V} \rightarrow \min )\end{array}$ & $\begin{array}{c}I I I \\
(U \rightarrow \min )\end{array}$ & $\begin{array}{c}\text { II } \\
(\bar{M}=0)\end{array}$ \\
\hline$p$ & $\frac{1}{2}$ al & $\frac{5}{8} 97$ & $\frac{2}{3}$ q1 \\
\hline$E-x=1$ & $\frac{91^{2}}{32}$ & & \\
\hline 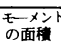 & $0.02083 q^{3}$ & $0.01237 \mathrm{ql}^{3}$ & $0.01235 q^{3}{ }^{3}$ \\
\hline
\end{tabular}

図一2 軸力の影䇾がない 1 变数問題における規漼 I， II，四の 比較

示した規準 $I$ の $|\bar{M}| \rightarrow \min$ はこの例においては, $\bar{M}=$ 0 と一致するので,ここでは式（2）の代わりに $\bar{M}=0$ を用いた。この例は 1 変数問題なので, 式 $(1),(2)$ を同時に満足する解は存在せず，別個に求められる．図 一2では結果をわかりやすく示すため，規準吕の解を中 央に，その左右に規準 I， II の解を示している.

図一2から次のことがいえる．規準 Iではモーメント $M$ のばらつきは小さいがプレストレス量 $P$ が小さす ぎ,プレストレスを導入した効果が小さく,そのためモー メントの面積が大きくなり，結果的に断面を大きくする 必要がある. 図一2右欗の規準 II はプレストレス量 $P$ が大きい，そのためケーブル取付位置でのモーメントが 大きくなり，その結果正曲げと負曲げの差が大きく，大 きな断面を必要とする．これに対し，規準 III は規準 I と II の中間の值をとり，モーメントの大きさとそのばらつ きともある程度満足した解となっている。

図一1の例ではプレストレスによる軸力の影響が全く 入っていなかった，そのため，同じく1 変数問題である が軸力の影響も考慮した図一3の構造物を考える。この 構造物に対して，上と同様にして規準 I， II，四に関し て計算した結果を図一4に示す。この例ではモーメント のばらつきに与える軸力の影響 $r_{v}$ と,ひずみエネルギー に及ぼす軸力の影響 $r_{v}$ の項が存在する， $r_{v}, r_{v}$ を実存 する斜張橋に関して計算した結果を表一1に示す.ここ では計算を簡単にするために, $\cos ^{2} \alpha / \sin ^{2} \alpha=1$ とし ている. 表一1をみれば明らかに $1 \gg r_{v}, 1 \gg r_{v}$ であり, 軸力の影響はほとんど無視できることがわかる．また規 準 I， IIによるP の值にはほとんど差がないが，規準 II では $P$ がかなり大きくなっている， $r_{v} ， r_{U}$ を無視し たときのモーメント図を图一4に示す，規準 II による モーメントは面積およびそのばらつきともに大きいが, 


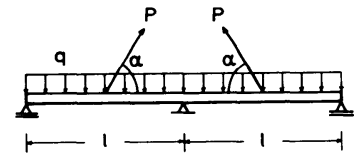

图一3 軸力の影䉕を考慮した 1 变数問題の例

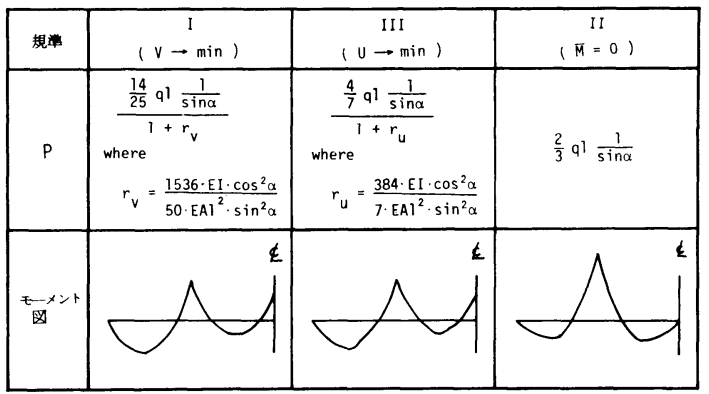

図一4 軸力の影整を考虔した 1 変数問題における規準 I， II, IIIの比較

表一1 軸力の影需 $r_{v}, r_{v}$

\begin{tabular}{|c|c|c|c|c|c|}
\hline 桶 & $1(n)$ & $A\left(\mathbf{m}^{2}\right)$ & $I\left(\nabla^{4}\right)$ & rv & ru \\
\hline 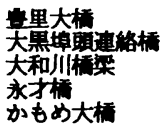 & $\begin{array}{l}218 \\
165 \\
355 \\
144 \\
240\end{array}$ & $\begin{array}{l}0.75 \\
0.8 \\
1.2 \\
0.33 \\
0.54\end{array}$ & $\begin{array}{l}0.98 \\
1.3 \\
2.7 \\
0.50 \\
1.01\end{array}$ & $\begin{array}{l}8.45 \times 10^{-4} \\
1.83 \times 10^{-3} \\
5.48 \times 10^{-4} \\
2.24 \times 10^{-3} \\
1.01 \times 10^{-3}\end{array}$ & $\begin{array}{l}1.50 \times 10^{-3} \\
3.27 \times 10^{-3} \\
8.79 \times 10^{-4} \\
4.01 \times 10^{-3} \\
1.80 \times 10^{-3}\end{array}$ \\
\hline
\end{tabular}

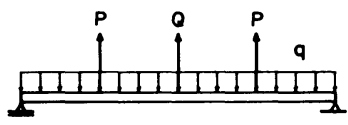

$1 \frac{1}{4}+\frac{1}{4}+\frac{1}{4}+\frac{1}{4}-1$

图-5 2 变数問題の例

規準 I， IIIでは適当なモーメント分布を示していること がわかる.

上記の例はいずれも 1 変数問題であったため,式( 1 ), （2）の規準 I，II を同時に満足した解は求まらなかっ た．そのため，図一5に示す 2 変数問題で，規準 I ，II を同時に満たした解と，規準而を満たした解との比較を 行う.この問題でも $|\bar{M}| \rightarrow \min は \bar{M}=0$ と一致するた め, 規準 I， II は $\bar{M}=0$ のもとで $V \rightarrow \min$ を求めるこ ととなる.この結果を表一2に示す．この結果から明ら かなように，規準吕の解では $\bar{M} \doteqdot 0$ となっており，ま たプレストレス $P$ および $Q$ に関しても規準 $I ， I I$ を満 たした解之規準西のそれとは非常に接近している.この ように規準用いれば，規準 I， II を同時に考えた解 とほとんど等しくなることがわかる.

では,より変数が多くなった場合ではどうであろうか. いま，もしプレストレスの值に何の制限も付加しなけれ
表一2 2 变数問題における規準 I，IIと四の比較

\begin{tabular}{|c|c|c|c|}
\hline & 规海 I，II & 規辈 III & 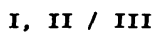 \\
\hline $\mathbf{P}$ & $\frac{14}{48} q 1=0.2917 q 1$ & $\frac{16}{56} q 1=0.2857 q 1$ & 1.021 \\
\hline $\mathbf{Q}$ & $\frac{11}{48} q 1=0.2292 q 1$ & $\frac{13}{56} q 1=0.2321 q 1$ & 0.987 \\
\hline M & 0 & $\frac{1}{1344} q 1^{2}$ & \\
\hline
\end{tabular}

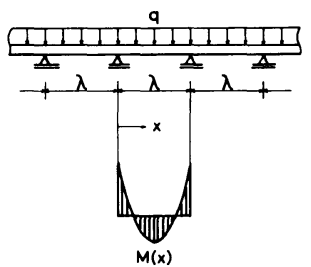

図一6 無限連続ばりにおける曲げモーメント分布

ば，規準ひずみエネルギー $U$ の最小值は $\partial U / \partial P_{i}$ $=0$ なる $i$ 点のプレストレス量 $P_{i}$ に関する多元連立一 次方程式を解くことにより求められる. カスチリアノの 定理によれば, $\partial U / \partial P_{t}$ は析のケーブル定着点のプレ ストレス方向の変位を表わし，これが零ということは妳 の曲げモーメント分布はケーブル定着点位置を支点とす る多点支持系のそれと同じになる，たとえば，図一6に 示す等分布荷重 $q$ を受ける 1 スパンの長さ $\lambda$ の無限連 続ばりを考えてみると，このはりの 1 スパンでの曲げ モーメント分布は

$$
M(x)=-\frac{1}{12} q \lambda^{2}+\frac{1}{2} q x(\lambda-x)
$$

であり，平均値は $\bar{M}=0$ となる，すなわち，極限的な マルチケーブルのはりを考えた場合，規準 I， II と規準 よる解は一致する。

すでに示したようにわずか 2 変数の場合でも規準 $I$, II を満たした解と規準四を満たした解はかなり接近して いる. さらにマルチケーブルになるにつれ両者の解はよ り接近し，極限的な状態では一致すると考えられる。こ のように考えるならば，規準 I，IIよりも数学的な取り 扱いが簡単な規準吕を採用して最適化を行う意義は十分 にあると考えられ，本研究では規準に基づきプレスト レス決定方法を議論する.

規準 IIIは曲げモーメントと軸力のあるより一般的な問 題では，次のような形のひずみエネルギーを用いて，

$$
U=\int_{0}^{l} \frac{M^{2}}{2 E I} d x+\int_{0}^{l} \frac{N^{2}}{2 E A} d x \rightarrow \min
$$

とする方がより合理的であろう.すなわち，断面力に対 応した剛度の逆数を重みとして付けることで断面剖度に 応じた断面力分布が得られるであろうということ，また 
曲げモーメントと軸力とを同時に取り扱うことができる という利点がある．このように，本研究においては，曲 げモーメントと軸力のひずみエネルギーを最小とする規 準を用いて，斜張橋ケーブルのプレストレス量を最適化 する問題を取り扱う。

3. 定式 化

\section{（1）記号}

定式化に用いた記号の意味を一括して以下に示す。

$2 n: 1$ 塔当たりのケーブル本数. 塔の左右でそ れぞれ $n$ 本ずつとする.

$m:$ 全部材数

$\{P \mid:$ プレストレスのつくるベクトル

$$
\left\{P_{1}, P_{2}, \cdots, P_{2 n}\right\}^{T}
$$

$\left\{T_{D}\right\},\left\{T_{L}\right\}$ : 死荷重 $(D)$ および活荷重 $(L)$ によって 生じるケーブル張力

$\left\{\boldsymbol{M}^{\eta}\right\},\left\{\boldsymbol{M}^{\top}\right\}$ : 部材両端（ $l$ 端と $r$ 端）の曲げモーメント

$\left\{M_{D}^{l}\right\},\left\{M_{D}^{\tau}\right\}$ : 死荷重によって部材両端に生じる曲げモ一 メント

$\left\{\boldsymbol{M}_{L}^{l}\right\},\left\{\boldsymbol{M}_{L}^{r}\right\}$ : 活荷重によって部材両端に生じる曲げモ一 メント

$\left\{M_{\mathrm{P}}^{l}\right\},\left\{M_{\mathrm{P}}^{T} ：\right.$ プレストレスによって部材両端に生じる曲 げモーメント

$\left\{N^{\natural}\right\},\left\{N^{\eta}\right\}$ : 部材両端の軸力

$\left\{N_{D}^{b}\right\},\left\{N_{D}^{r}\right\}$ : 死荷重によって部材両端に生じる軸力 $\left\{N_{l}^{l}\right\},\left\{N_{l}^{r}\right\}$ : 活荷重によって部材両端に生じる軸力

$\left\{N_{P}^{l}\right\},\left\{N_{P}^{v} ：\right.$ プレストレスによって部材両端に生じる軸 力

$\left[C^{\imath}\right],\left[C^{r}\right]:$ 第 $j$ ケーブルのプレストレスが単位量変 化したときの第 $i$ 部材の両端の曲げモーメ ントの変化量 $C_{i j}^{l}$ および $C_{i j}^{r}$ のつくる影響 行列

$\left[D^{l}\right],\left[D^{r}\right]$ : プレストレスの軸力に対する影響行列

\section{(2) 断 面 力}

斜張橋の完成系（図一7(a)）と，その系からケーブル を除去し代わりにケーブル張力と同じ大きさと方向の力 を外力として作用させた系 (図一7(b)) とは構造的に 等価であると考える. 次に，後者の系の外力を未知量で あるプレストレス $P$ および既知量である荷重によって 生じる張力 $T_{w}$ とに分解する (図一7 $\left.\left(\mathrm{c}_{1}\right),\left(\mathrm{c}_{2}\right)\right)$. この ような分解によって，プレストレスが断面力に与える影 響をみることが容易になる。たとえば，プレストレスの 断面力に対する影響行列 $\left[C^{l}\right],\left[C^{r}\right],\left[D^{l}\right],\left[D^{r}\right]$ は図一 $7\left(c_{1}\right)$ から求めることができる.

桁および塔の断面力は, プレストレスの関数として $\left\{M^{l}\right\}=\left\{M_{D}^{l}\right\}+\left\{M_{L}^{l}\right\}+\left\{M_{P}^{l}\right\}=\left\{M_{D}^{l}\right\}+\left\{M_{L}^{l}\right\}+\left[C^{l}\right]\{P\} \cdots(6)$ $\left\{M^{r}\right\}=\left\{M_{D}^{r}\right\}+\left\{M_{L}^{r}\right\}+\left\{M_{P}^{r}=\left\{M_{D\}}^{r}+\left\{M_{L}^{r}\right\}+\left[C^{r}\right]\{P\} \cdots(7)\right.\right.$

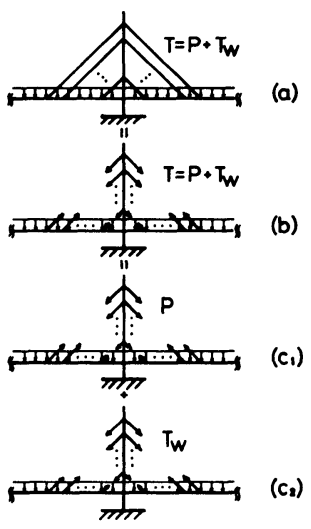

図一7 等価系のモデル図

$$
\begin{aligned}
& \left\{N^{\eta}\right\}=\left\{N_{D}^{l}\right\}+\left\{N_{L}^{l}\right\}+\left\{N_{P}^{l}\right\}=\left\{N_{D}^{l}\right\}+\left\{N_{L}^{l}\right\}+\left[D^{l}\right]\{P\} \\
& \left\{N^{r}\right\}=\left\{N_{D}^{r}\right\}+\left\{N_{L}^{r}\right\}+\left\{N_{P}^{r}\right\}=\left\{N_{D}^{r}\right\}+\left\{N_{L}^{r}\right\}+\left[D^{r}\right]\{P\}
\end{aligned}
$$

と表わせる。

（3）制約条件

a ）死荷重完成時に塔に曲げを生じない

図一8に示すように $\varphi_{i}$ を第 $i$ ケーブルと水平とのな す角とする．死荷重完成時において塔に曲げを生じない ための条件は

$\left(T_{D}+P\right)_{i} \cos \varphi_{i}=\left(T_{D}+P\right)_{2 n+1-i} \cos \varphi_{2 n+1-i}$

となる.この式を変形すると

$$
P_{2 n+1-i}=\pi_{i} P_{i}+\Delta T_{D i}
$$

が得られる.ここに,

$$
\pi_{i}=\cos \varphi_{i} / \cos \varphi_{2 n+1-i}
$$

$$
\Delta T_{D i}=\pi_{i} T_{D i}-T_{D 2 n+1-i}
$$

である. 式（11）をすべてのケーブルについて表わすと

$$
\{P\}=[\pi]\{\bar{P}\}+\left\{\Delta T_{D}\right\}
$$

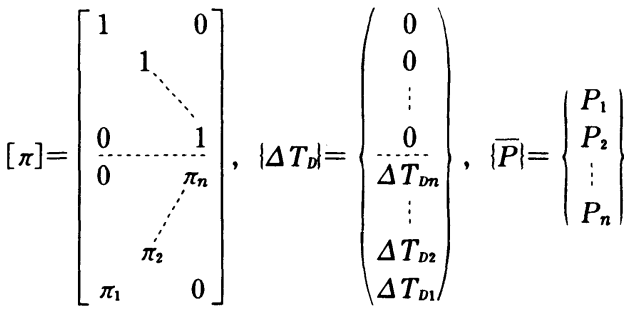

となる.

b ） プレストレス量の制限

ケーブル張力の上限を $\left\{T_{u}\right\}$, またケーブル張力の下限 を $\left\{T_{l}\right\}$ とすると

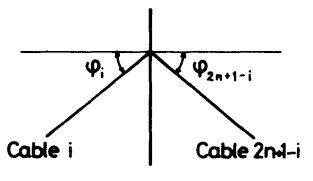

図一8 ケーブルのモデル図 
$\left\{T_{u}\right\} \leqq\left\{T_{D}\right\}+\left\{T_{L}\right\}+\left\{P \mid \leqq\left\{T_{u}\right\}\right.$

あるいは

$\left\{P_{l}\right\} \leqq\{P\} \leqq\left\{P_{u}\right\}$

ここに

$$
\begin{aligned}
& \left\{P_{l}\right\}=\left\{T_{l}\right\}-\left\{T_{D}\right\}-\left\{T_{L}\right\} \\
& \left\{P_{u}\right\}=\left\{T_{u}\right\}-\left\{T_{d}\right\}-\left\{T_{L}\right\}
\end{aligned}
$$

となる.ところが，a) でプレストレス相互に従属関係 を与えて変数を半減しているため, 式 $(16)$ を半分の変 数になった $\{\bar{P}\}$ に関する条件式に書き換える必要があ る.

第 $2 n+1-i(1 \leqq i \leqq n)$ ケーブルについて

$P_{l 2 n+1-i} \leqq P_{2 n+1-i} \leqq P_{u 2 n+1-i}$

式（11）を代入し， $\pi_{i}>0$ を考虑すると

$\left(P_{i 2 n+1-i}-\Delta T_{D i}\right) / \pi_{i} \leqq P_{i} \leqq\left(P_{u 2 n+1-i}-\Delta T_{D i}\right) / \pi_{i}$

したがって $\bar{P} \mid$ に対する条件としては

$$
\left\{\bar{P}_{l}\right\} \leqq\left\{\bar{P} \mid \leqq\left\{\bar{P}_{u}\right\}\right.
$$

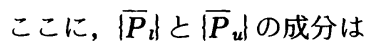

$$
\begin{aligned}
& \bar{P}_{l i}=\max \left\{P_{l i}, \quad\left(P_{l 2 n+1-t}-\Delta T_{D t}\right) / \pi_{t}\right\} \\
& \bar{P}_{u l}=\min \left\{P_{u l}, \quad\left(P_{u 2 n+1-t}-\Delta T_{D i}\right) / \pi_{i}\right\}
\end{aligned}
$$

となる。

\section{(4) 目的関数}

目的関数であるひずみエネルギーUは，せん断力の 影響を無視すると

$$
\begin{aligned}
& U=\sum_{i=1}^{m} \frac{1}{2 E I_{i}} \frac{l_{t}}{2}\left\{\left(M_{i}^{t}\right)^{2}+\left(M_{i}^{T}\right)^{2}\right\}+\sum_{i=1}^{m} \frac{1}{2 E A_{i}} \frac{l_{t}}{2}\left\{\left(N_{i}\right)^{2}\right. \\
& \left.+\left(N_{i}^{T}\right)^{2}\right\}
\end{aligned}
$$

で表わされる.ここで，断面力に対して次の変換を考え る。すなわち,

$$
\begin{aligned}
& \left\{\bar{M}^{\eta}\right\}=[\alpha]\left\{M^{2}\right\} \\
& \left\{\bar{M}^{\gamma}\right\}=[\alpha]\left\{M^{\gamma}\right\} \text {. } \\
& \left\{\bar{N}^{y}\right\}=[\beta]\left\{N^{\eta}\right\} \\
& \left\{\bar{N}^{\gamma}\right\}=[\beta]\left\{N^{\eta}\right\}
\end{aligned}
$$

$$
\text { ここに, }
$$$$
[\alpha]=\left[\begin{array}{lllll}
\sqrt{l_{1} / 4 E I_{1}} & & & \\
& \sqrt{l_{2} / 4 E I_{2}} & & \\
& & \ddots & \\
& & \ddots & \\
& & & \sqrt{l_{m} / 4 E I_{m}}
\end{array}\right]
$$

$$
[\beta]=\left[\begin{array}{llll}
\sqrt{l_{1} / 4 E A_{1}} & & & \\
& \sqrt{l_{2} / 4 E A_{2}} & & \\
& & \ddots & \\
& & & \ddots \\
& & & \sqrt{l_{m} / 4 E A_{m}}
\end{array}\right]
$$

このとき,ひずみエネルギーは

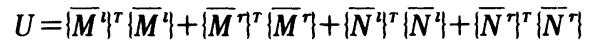

$$
=\{F\}^{r}\{F\}
$$

$\{F\}=\left\{\begin{array}{llll}\bar{M}^{l} & \bar{M}^{r} & \bar{N}^{l} & \bar{N}^{r}\end{array}\right\}^{r}$
で表わされる. 式（30）に式（6)（9）を代入して $\{F\}$ を $\{P\}$ で表わすと,

$$
\begin{aligned}
& \left.\{F\}=\left[\begin{array}{cccc}
\alpha & & & 0 \\
& \alpha & & \\
& & \beta & \\
0 & & & \beta
\end{array}\right]\left(\begin{array}{c}
M_{D}^{l} \\
M_{D}^{r} \\
N_{D}^{l} \\
N_{D}^{r}
\end{array}\right)+\left(\begin{array}{c}
M_{L}^{l} \\
M_{L}^{r} \\
N_{L}^{l} \\
N_{L}^{r}
\end{array}\right)+\left[\begin{array}{c}
C^{l} \\
C^{r} \\
D^{l} \\
D^{r}
\end{array}\right]\{P\}\right) \\
& =\left\{F_{D L}\right\}+[\overline{C D}]\{P\}
\end{aligned}
$$

$$
\left.\left\{F_{D L}\right\}=\left[\begin{array}{cccc}
\alpha & & & 0 \\
& \alpha & & \\
& & \beta & \\
0 & & & \beta
\end{array}\right]\left(\begin{array}{c}
M_{D}^{l} \\
M_{D}^{r} \\
N_{D}^{l} \\
N_{D}^{r}
\end{array}\right)+\left(\begin{array}{c}
M_{L}^{l} \\
M_{L}^{r} \\
N_{L}^{l} \\
N_{L}^{r}
\end{array}\right)\right),
$$

$$
[\overline{C D}]=\left[\begin{array}{llll}
\alpha & & & 0 \\
& \alpha & & \\
& & \beta & \\
0 & & & \beta
\end{array}\right]\left[\begin{array}{l}
C^{l} \\
C^{r} \\
D^{l} \\
D^{r}
\end{array}\right]
$$

さらに，制約条件式（14）を代入すると

$$
\begin{aligned}
\{F\} & =\left\{F_{D L}\right\}+[\overline{C D}]\left([\pi]\{\bar{P}\}+\left\{\Delta T_{D D}\right)\right. \\
& =\left\{F_{0}\right\}+[X]\{\bar{P}\} \ldots \ldots \ldots \ldots \ldots \ldots \ldots
\end{aligned}
$$

ここに,

$$
\begin{aligned}
& \left\{F_{0}\right\}=\left\{F_{D L}\right\}+[\overline{C D}]\left\{\Delta T_{D}\right\} \\
& {[X]=[\overline{C D}][\pi]}
\end{aligned}
$$

となり，ひずみエネルギーはプレストレスの関数として 次のように表わされる.

$$
\begin{aligned}
U & \left.=\left(\left\{F_{0}\right\}+[X] \mid \bar{P}\right\}\right)^{T}\left(\left|F_{0}\right|+[X]\{\bar{P}\}\right) \\
& =\left\{F_{0}\right\}^{T}\left\{F_{0}\right\}+2\left|F_{0}\right|^{T}[X]\{\bar{P}\}+\{\bar{P}\}^{T}[X]^{T}[X]\{\bar{P}\} \cdots(33)
\end{aligned}
$$

最終的に，式（33）で表わされるひずみエネルギーを， 制約条件式(21)のもとで解くことになる.この解法には, 種々の最適化手法が利用できるが, 本研究においては共 役勾配法を用いた ${ }^{4), 5}$.

\section{4. 計算例および考察}

いくつかの実橋を対象に，本研究で提案したひずみ工 ネルギー規準を適用して最適なケーブルプレストレスを 求めた結果を以下に示す. 計算例として用いたのは, 豊 里大橋, 大黒埠頭連絡橋, 大和川橋梁, 永才橋, かもめ 大橋，六甲アイランド連絡橋の 6 橋である. なお，これ らの橋の設計条件は必ずしも本研究の方法で仮定した設 計条件と一致していないが, 本研究の方法の有用性の確 認のため実橋の諸元を例として使用する.これらの橋に 関して, 本研究で示した手法により求めた最適プレスト レスの值を表一3 8に，析の断面力図を図一9１4に示 す. 図中実線はプレストレス導入後の断面力, 破線はプ レストレス導入前の断面力を表わしている. また表一 9 に図一9〜14 から求めたプレストレス導入前後の断面力 の平均値, 断面力の標準偏差を示す。なお，これらの計 算において，プレストレスは実橋の死荷重状態を対象と して決定し，活荷重は考慮しなかった。 


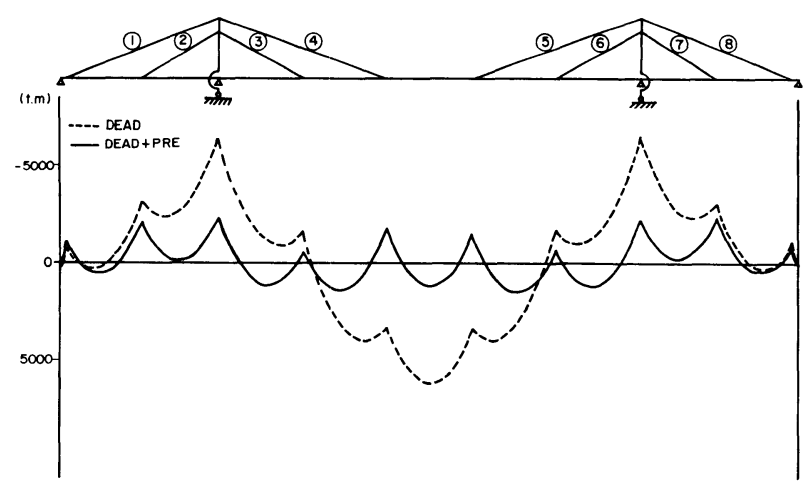

図一9輼里大橋における曲げモーメント分布

表一3豊里大橋における最適プレストレスと ケーブル張力 (単位: $t$ )

\begin{tabular}{|r|r|r|}
\hline No. & PRE & PRE+DEAD \\
\hline (1) & 323.1 & 1701.3 \\
\hline$(2)$ & 86.0 & 949.0 \\
\hline$(3)$ & -153.7 & 921.7 \\
\hline$(4)$ & 446.4 & 1675.4 \\
\hline 5 & 389.4 & 1611.4 \\
\hline 6 & -140.3 & 946.5 \\
\hline 7 & 122.9 & 973.3 \\
\hline 8 & 253.2 & 1634.7 \\
\hline
\end{tabular}

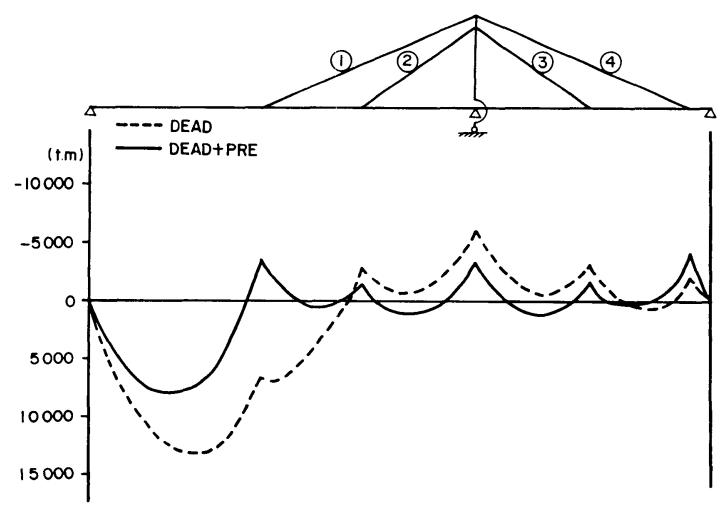

図一10大黒嬶頭連絡橋における曲げモーメント分布

図一9および表一3 は豊里大橋における計算結果であ る. プレストレス導入前では支間中央と塔基部支点で大 きな曲げモーメントが出現しているが, 本研究で提案し たひずみエネルギー規準によるプレストレスを導入する と, 図から明らかなように, 断面力分布が均等化し, か つ断面力そのものも小さくなっていることがわかる.こ のことは表一9の断面力の平均値や標準偏差からも明ら かである. 表一3の最適プレストレスの值をみると, 負 のプレストレスが存在する、これはケーブルをゆるめる ことを意味しているが, この件に関しては後に考察を加 える.
表一4 大黒埠頭連絡橋における

最適プレストレスとケー ブル張力 (単位: $\mathrm{t}$ )

\begin{tabular}{|c|c|c|}
\hline No. & PRE & PRE+DEAD \\
\hline (1) & 1074.2 & 2466.7 \\
\hline (2) & -480.0 & 865.4 \\
\hline (3) & -141.8 & 875.4 \\
\hline (4) & 884.2 & 2487.5 \\
\hline
\end{tabular}

表一5 大和川橋梁における最適プレストレスとケー ブル張カ (単位 : $\mathrm{t}$ )

\begin{tabular}{|r|r|r|r|r|r|}
\hline No. & \multicolumn{1}{|c|}{ PRE } & DEAD+PRE & No. & \multicolumn{1}{|c|}{ PRE } & DEAD+PRE \\
\hline (1) & 375.9 & 3429.6 & 9 & 374.6 & 3341.2 \\
\hline 2 & -304.4 & 1994.1 & 10 & -333.2 & 2016.4 \\
\hline 3 & 346.7 & 2170.9 & 11 & 326.5 & 2202.8 \\
\hline (4) & 576.7 & 1832.3 & 12 & 422.4 & 1709.7 \\
\hline (5) & 567.3 & 1832.3 & 13 & 479.5 & 1709.7 \\
\hline 6 & 301.9 & 2170.9 & 14 & 396.2 & 2202.8 \\
\hline 7 & -374.3 & 1994.1 & 15 & -288.0 & 2016.4 \\
\hline (8) & 454.0 & 3429.6 & 16 & 285.0 & 3341.2 \\
\hline
\end{tabular}

表一6 永才橋における最適プレストレスと ケーブル張力 (単位: $\mathrm{t}$ )

\begin{tabular}{|r|r|r|}
\hline No. & \multicolumn{1}{|c|}{ PRE } & PRE+DEAD \\
\hline 1 & 750.7 & 969.5 \\
\hline (2) & -178.8 & 100.0 \\
\hline 3 & -141.9 & 100.0 \\
\hline (4) & -90.5 & 159.2 \\
\hline 5 & 56.8 & 237.3 \\
\hline 6 & 99.2 & 238.7 \\
\hline (7) & 141.2 & 239.2 \\
\hline 8 & 101.8 & 237.8 \\
\hline 9 & -38.3 & 159.5 \\
\hline 19 & -107.1 & 100.2 \\
\hline (11) & -175.0 & 100.2 \\
\hline (12) & 637.2 & 971.2 \\
\hline
\end{tabular}

図一10および表一4 4 は大黒埠頭連絡橋の場合である が, プレストレスを導入することによって，この例でも 断面力とそのばらつきとも非常に小さくなっていること がわかる. しかしこの橋においては, 左支点とケーブル 1 の定着点間の距離が長く,この部分の曲げモーメント が他に比べて大きくなっている.これは, ケーブル 1 に さらにプレストレスを導入すれば改善されるであろう が, 逆に他の部分の曲げモーメントが増加し, 全体とし て断面力分布のバランスが崩れることになろう.

図一11，12，13 および表一5，6，7 と豊里大橋に比へ てケーブル本数が多くなり，そのため決定すべきプレス トレス量も多くなるが, 本手法では問題なく最適解が得 られていることがわかる.なお表一6および7において， $\mathrm{PRE}+\mathrm{DEAD}$ の值が $100.0 \mathrm{t}$ もしくは50.0 $\mathrm{t}$ となって いるものがあるが, これはケーブル張力の下限制約がア クティブとなったためである.

図一12 の永才橋, 図一13 のかもめ大橋とケーブル本 数が多いマルチケーブル形式になると, ケーブル 1 本当 


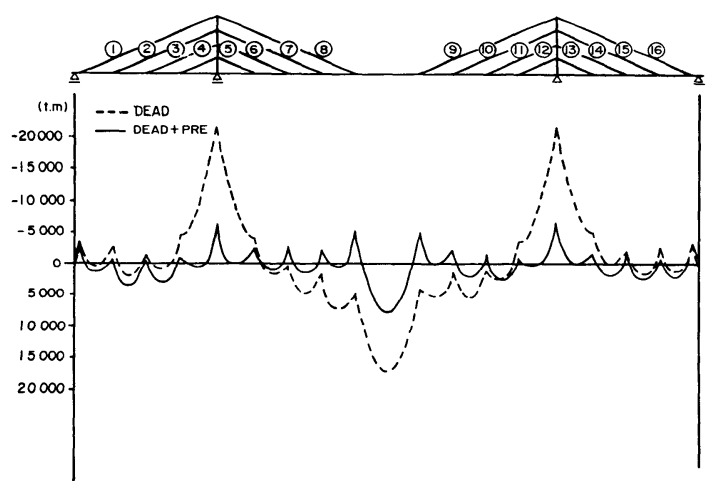

図一11大和川橋梁における曲げモーメント分布

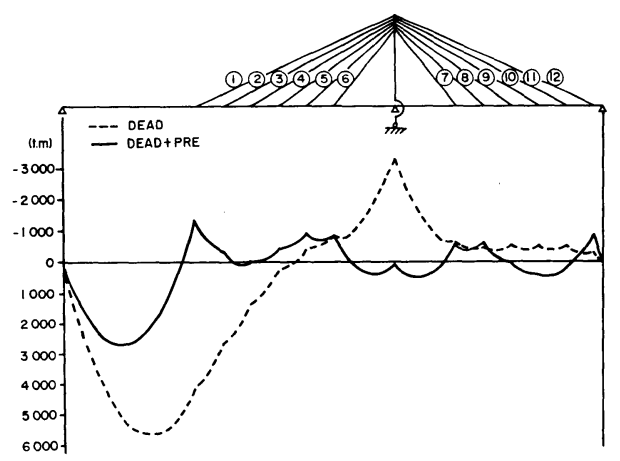

図一12 永才橋における曲げモーメント分布

たりの影響は小さくなり，上段および下段ケーブルの定 着点が支点となる形を示す．これらは後で考察する負の ケーブルプレストレスとも関連がある.

図一14 および表一8 は補䒽桁がトラスである六甲アイ ランド連絡橋の例である. 補剛枌の種類にかかわらず,
表一7 かもめ大橋における最適プレストレスとケーブル張カ (単位 $: t$ )

\begin{tabular}{|r|r|r|r|r|r|}
\hline No. & PRE & PRE+DEAD & No. & \multicolumn{1}{|c|}{ PRE } & PRE+DEAD \\
\hline$(1)$ & 1178.0 & 1598.0 & 21 & 939.1 & 1290.9 \\
\hline 2 & -300.3 & 103.9 & 22 & -122.5 & 236.1 \\
\hline 3 & -285.2 & 104.1 & 23 & -176.5 & 185.7 \\
\hline 4 & -271.4 & 104.3 & 24 & -223.9 & 139.8 \\
\hline 5 & -122.7 & 104.5 & 25 & -127.3 & 100.0 \\
\hline 6 & -116.1 & 104.7 & 29 & -127.4 & 100.0 \\
\hline 7 & -110.4 & 105.0 & 27 & -127.5 & 100.0 \\
\hline 8 & -105.3 & 105.4 & 28 & -128.0 & 100.0 \\
\hline 9 & -86.1 & 52.9 & 29 & -104.3 & 50.0 \\
\hline 10 & 562.6 & 697.6 & 39 & 548.8 & 703.0 \\
\hline 11 & 501.7 & 656.0 & 39 & 614.5 & 749.5 \\
\hline 12 & -104.4 & 50.0 & 32 & -86.0 & 53.0 \\
\hline 13 & -128.2 & 100.0 & 33 & -105.1 & 105.6 \\
\hline 14 & -127.8 & 100.0 & 34 & -110.3 & 105.3 \\
\hline 15 & -127.6 & 100.0 & 35 & -116.1 & 105.0 \\
\hline 16 & -127.6 & 100.0 & 36 & -122.7 & 104.7 \\
\hline 17 & -264.3 & 100.0 & 37 & -230.1 & 146.1 \\
\hline 18 & -262.8 & 100.0 & 38 & -196.1 & 193.6 \\
\hline 19 & -259.4 & 100.0 & 39 & -158.8 & 245.8 \\
\hline 29 & 1188.5 & 1541.0 & 49 & 922.0 & 1341.8 \\
\hline
\end{tabular}

表一8 六甲アイランド連絡橋における最適プレストレスとケー ブル張力 (単位: $t$ )

\begin{tabular}{|r|c|c|r|r|r|}
\hline No. & PRE & PRE+DEAD & No. & \multicolumn{1}{|c|}{ PRE } & PRE+DEAD \\
\hline (1) & 385.3 & 613.9 & 11 & 455.3 & 624.4 \\
\hline 2 & 190.2 & 424.4 & 12 & 178.4 & 386.1 \\
\hline$(3)$ & 103.9 & 340.2 & 13 & 91.5 & 334.4 \\
\hline 4 & 120.8 & 352.3 & 14 & 71.1 & 342.1 \\
\hline 5 & 273.3 & 487.1 & 15 & 182.8 & 469.1 \\
\hline 6 & 176.8 & 469.1 & 16 & 267.3 & 487.1 \\
\hline 7 & 67.9 & 341.6 & 17 & 118.5 & 352.9 \\
\hline 8 & 88.2 & 331.4 & 18 & 106.5 & 343.3 \\
\hline 9 & 208.7 & 414.9 & 19 & 162.2 & 395.0 \\
\hline 19 & 435.6 & 601.7 & 89 & 411.4 & 637.1 \\
\hline
\end{tabular}

本手法によって最適なプレストレスが求まっていること がわかる.この六甲アイランド連絡橋のようなトラス形

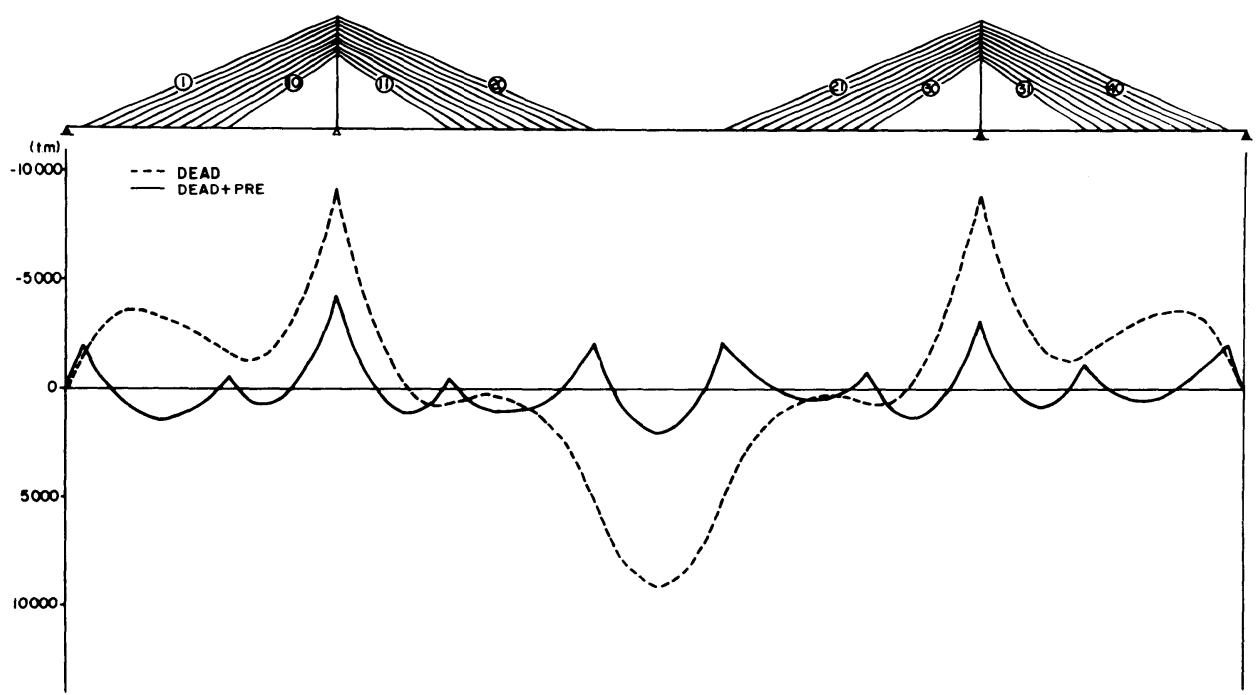

図一13 かもめ大橋における曲げモーメント分布 


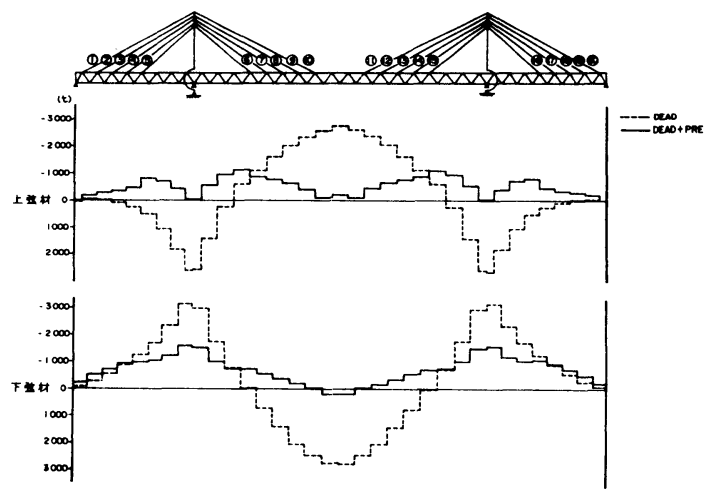

図一14 六甲アイランド連絡橋における上・下弦材軸力分布

表一9 プレストレス满入前後の断面力の平均值および断面力の 模激偋差

\begin{tabular}{|c|c|c|c|}
\hline 橋 & 荷 重 & 平 均 值 & 標䇤 偏差 \\
\hline \multirow{2}{*}{ 豊里 大楿 } & D & $-227.7 \mathrm{tw}$ & $3228.8 \mathrm{tm}$ \\
\hline & $\mathbf{D}+\mathbf{P}$ & $-92.7 \mathrm{tm}$ & $1093.4 \mathrm{tm}$ \\
\hline \multirow{2}{*}{$\begin{array}{c}\text { 大黒 埠頭 } \\
\text { 連絡㛢 } \\
\end{array}$} & D & $2239.1 \mathrm{tm}$ & $5589.4 \mathrm{tm}$ \\
\hline & $D+P$ & $799.1 \mathrm{tm}$ & $3142.3 \mathrm{tm}$ \\
\hline \multirow{2}{*}{ 大和川橋梁 } & D & $-625.4 \mathrm{tm}$ & $7923.3 \mathrm{tm}$ \\
\hline & $\mathrm{D}+\mathrm{P}$ & $-49.0 \mathrm{tm}$ & $2971.7 \mathrm{tm}$ \\
\hline \multirow{2}{*}{ 永才橋 } & D & $874.9 \mathrm{tm}$ & $2454.7 \mathrm{tm}$ \\
\hline & $D+P$ & $253.8 \mathrm{tm}$ & $978.8 \mathrm{tm}$ \\
\hline \multirow{2}{*}{ かもめ大楿 } & $\mathrm{D}$ & $-587.6 \mathrm{tm}$ & $3913.9 \mathrm{tm}$ \\
\hline & $\mathrm{D}+\mathrm{P}$ & $-178.9 \mathrm{tm}$ & $1235.8 \mathrm{tm}$ \\
\hline \multirow{2}{*}{$\begin{array}{l}\text { 六甲アイラ } \\
\text { ンド上弦材 }\end{array}$} & D & $-266.0 \mathrm{t}$ & $1499.5 \mathrm{t}$ \\
\hline & $D+P$ & $-548.3 \mathrm{t}$ & $314.3 \mathrm{t}$ \\
\hline \multirow{2}{*}{$\begin{array}{l}\text { 六甲アイラ } \\
\text { ンド下弦材 }\end{array}$} & D & $-336.7 \mathrm{t}$ & $1759.1 \mathrm{t}$ \\
\hline & $D+P$ & $-717.1 \mathrm{t}$ & $489.8 \mathrm{t}$ \\
\hline
\end{tabular}

D：死荷重のみ(プレストレス導入前)

$\mathrm{D}+\mathrm{P}:$ 死荷重 + ブレストレス（プレストレス導入後）

式の補剛析においては, 弦材軸力は主構の曲げによって 生じるものと, ケーブル張力によって生じるものとが合 成されている. プレストレスを導入すれば, 後者が増加 してその平均値は導入前より少し大きくなるが, 曲げに よる軸力が大幅に改善されてばらつきが非常に小さく なっている，そのため，表一9に示すプレストレス導入 による弦材軸力の平均値増加は問題とならないと考えら れる.

また，軸力およびせん断力の分布について，大和川橋 梁を例として図一15，16 に示すが，軸力は過大に導入 されておらず，せん断力分布も曲げモーメント分布が均 一化されたため, 良好なものとなっている.

さて, 以上の図表から本研究で提案したひずみエネル ギー規準によりプレストレス導入の目的である断面力分 布を均等化し，かつ断面力をできるだけ小さくするとい う点については十分満足できる結果が得られていること

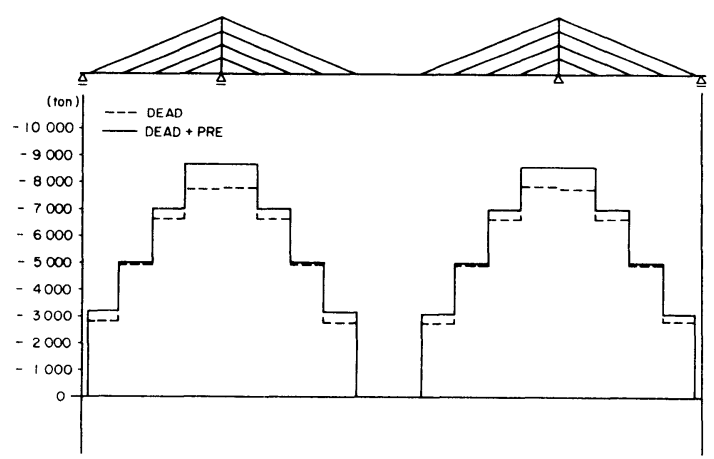

図一15大和川橋梁における軸力分布

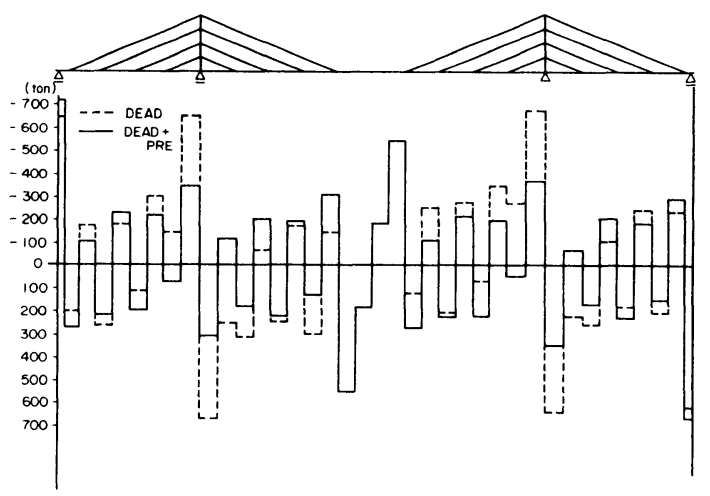

图一16 大和川橋梁におけるせん断力分布

がわかる. 数值的には表一9に示したとおりであるが, 断面力の平均値はトラス橋である六甲アイランド連絡橋 を除いてかなり減少しており，またばらつきもすべての ケースで大きく減少している.

表一3〜8に示すプレストレスには六甲アイランド連 絡橋を除いてはすでに述べたように負の值が存在してい る. ケーブル本数の少ない豊里大橋と大黒埠頭連絡橋に ついては下段ケーブルに, マルチケーブルの大和川橋梁, 永才橋，かもめ大橋では中段ケーブルに負のプレストレ スが現われている. 上段ケーブルの正のプレストレスは 支間中央部の曲げを改善し，桁にとっては上段ヶーブル の定着点が支点となることを意味する，その上，中段あ るいは下段に正のプレストレスを導入すると, 支間中央 の曲げが逆に大きくなるため負のプレストレスが導入さ れたのであろう. またママルチケーブルにおいては上段お よび下段ケーブルの定着点が支点となる断面力分布を示 すが，さらに中段ケーブルに正のプレストレスを導入す ると塔基部支点上の妳のいわゆる負曲げが大きくなるた めである.なお，六甲アイランド連絡橋は補剛桁がトラ ス形式で剛性が高く, 上段あるいは下段ケーブルの定着 点が支点としての働きをなさないため全体に正のプレス トレスが導入されたものと考えられる. 
普通，設計者が試行によってプレストレスを決定する 場合,負の值まで考えることはかなり難しいことであり， 負の值を考虑したとしても上段，中段および下段のケ一 ブルのプレストレスをバランスよく決定することはほと んぞ不可能であろう. その点, 本研究の方法では負のプ レストレスを有効に利用し，桁の断面力をバランスよく 自動的に決定することができる.

ただし，本研究の方法による場合 3. (3)，b) で示し たケーブル張力の上，下限値の設定に注意を要する．上 限值については仮定したケーブル断面から許容される值 とするが，下限値については構造解析で影響線解析を用 いる関係上ケーブルが線形とみなせる範讲のみでなく, ケーブルの疲労なども考慮して決定すべきである.

プレストレスを決定する場合の対象とする荷重状態 は，活荷重による曲げモーメント分布が全スパンにわ たって比較的一様となる場合には，死荷重でよいと考え られる。これは死荷重十活荷重による設計モーメントも 比較的一椂となるからである. 本研究ではこのように考 えて死荷重のみを用いたが, 非対称の斜張橋などでは, 活荷重による曲げモーメント分布は一様にならないた め, 活荷重を考慮したプレストレス決定を行う必要があ ろう.

曲げモーメント分布は支間割りとケーブル配置に大き く左右されていることがわかる.ケーブル定着点および 支点の間隔がほぼ等しい豊里大橋では曲げモーメント分 布の均等化がよくなされている. また，かもめ大橋にお いても中段部ケーブルに張力があまり導入されてなく， 同様の結果を示している.これに対し，大黒埠頭連絡橋 や大和川橋梁ではケーブル定着点間距離が大きい部分 で，大きな断面力を示している．河川あるいは海峡など 立地条件から支間割りは制約を受け，必ずしも望ましい 形状を保つことは難しいが，塔の高さによりヶーブル配 置を調整し，できる限り等しい支点および定着点間距離 とするのがよいであろう. 逆に本手法を用いて最適プレ ストレスを決定した後の断面力が均等化できていなけれ ば，支間割りやケーブル配置を再考すればよいこともわ かる.

\section{5. 結 論}

本研究で得られた結論は以下のように要約することが できる.

（1）ひずみエネルギー規準による最適プレストレス
決定は，断面力分布を均等化し，かつその断面力をでき るだけ小さくするというプレストレス導入の目的を簡単 な計算で自動的に達成できる。

（2）斜張橋の枌の断面力の改善には正のプレストレ スだけでなく, 死荷重状態よりさらに張力を減少させる 負のプレストレスを有効に活用する必要がある．それは 本研究で示したひずみエネルギー規準により簡単に行う ことができる.

（3）断面力分布は支間割りおよびケーブル配置に支 配され，これらはなるべく均等とすることが望ましい． 本研究によるプレストレスの導入は, 適切な支間割りと ケーブル配置がなされた斜張橋に対し最も有効である.

本研究で提案したひずみエネルギー規準は斜張橋ケー ブルの最適プレストレス量の決定に大いに有効である. そのため,このプレストレス決定方法を従来行われてき た斜張橋全体の最適設計ルーチンとして組み込むことも 可能である.

今回のプレストレス決定で用いた仮定はすべての設計 条件を満たしたものでなく，代表的なものを採用したに すぎない，特に，斜張橋の設計においては架設条件が重 要であり，たとえば前死荷重時に閉合部の曲げが零とな るという制約条件なよ゙も考慮する必要があり，そのよう な場合にも適用できるよう今後研究を進める予定であ る.

最後に，計算例に使用した実橋の資料を提供いただい た担当各局に深く感謝の意を表わします.

\section{参 考 文 献}

1）小西一郎編：鋼橋設計編 II, 丸善, pp. 952 -957, 昭和 51 年.

2）山田善一・大宮司尚：斜張橋の最適基準設計に関する研 究, 土木学会論文報告集, 第 253 号, pp. 1 12, 1976 年 9 月.

3）前田幸雄・林正・鞆 一：斜張橋の最適設計法, 日本鋼構造協会第 13 回大会研究集会マトリックス解析法 研究発表論文集, pp. $321 \sim 326$, 昭和 54 年 6 月.

4) Fletcher, E. and Reeves, C. M. : Function Minimization by Conjugate Gradients, Computer Journal, Vol. 7, pp. 149 154, 1964.

5) Dixon, L. C.W. : On Conjugate Gradient Algorithms, in Dixon, Spedicato, Szego ed., Nonlinear Optimization, pp. 123 135, Birkhauser, Boston, 1980.

(1984.7.13 - 受付) 